A - preparing concepts

$\mathrm{B}$ - formulating methods

$\mathrm{C}$ - conducting research

$\mathrm{D}$ - processing results

E - interpretation and conclusions

$\mathrm{F}$ - editing the final version

\section{Work motivating and demotivating factors in the perspective of occupational therapists}

\author{
Adrianna Wajda ${ }^{A-C, F}(\mathbb{D})$, Edyta Janus *A,C-E (iD) \\ University of Physical Education, Kraków, Poland
}

*Correspondence: Edyta Janus; University of Physical Education, Kraków, Poland; Accepted: 2020-08-06 email: edyta.janus@awf.krakow.pl

\begin{abstract}
Introduction: Identifying factors which influence work motivation levels in Polish occupational therapists is both a challenge and a necessity. Unfortunately, this issue is not given proper consideration. Determining motivating and demotivating factors should be the fundament on the basis of which employers can design their actions aimed at raising their organizations' human resources, and on which they can base when they strive to increase the level of services provided by occupational therapists.

Material and methods: To select the study population, we used nonprobability sampling. The study population consisted of 295 professionally active occupational therapists employed in Poland. To conduct the study, we used the diagnostic survey method and the technique of questionnaire. The study tool was a questionnaire we designed for the purpose of this study.

Results: Work motivating factors that the respondents reported most often were: high level of satisfaction from the stability and safety of employment, being able to observe the effects of their therapeutic actions in their patients, the feeling of helping another human being, the quality of interpersonal relationships at work. The most commonly reported demotivating factor was receiving remuneration which was inadequate to the work performed. Other demotivating factors were: lack of general understanding for the role of an occupational therapist and for the potential of occupational therapy in comprehensive rehabilitation.

Conclusions: Our respondents reported non financial work motivating factors and appreciated them highly. According to the respondents, the factors that could increase their work motivation were: salary increase as well as promoting reliable information on occupational therapy and its potential.
\end{abstract}

Keywords: motivation, professional work, occupational therapy

\section{Introduction}

An increase in demand for care workers places them in the focus of attention. As regards type of profession, occupational therapists are sometimes considered to be care workers, and sometimes to be health care workers. Their work, where they support clients who struggle with numerous limitations, may burden them significantly. This is why it is essential to support their broadly understood wellbeing, as well as to maintain their adequate work motivation.

This is an Open Access journal, all articles are distributed under the terms of the Creative Commons Attribution-NonCommercial-ShareAlike 4.0 International (CC BY-NC-SA 4.0). License (http://creativecommons. org/licenses/by-nc-sa/4.0/). 
The term "motivation" stems from the Latin word motus and it means: moving, stirring, inspiring, influencing, stimulating for action [1]. In its general meaning, it refers to factors that affect people to spur them into certain action. These factors are referred to as motivators. Motivators, understood as stimuli, have two basic functions: they stimulate employees to action which is required by an organization, and they satisfy values and needs of individuals [2]. There are two types of motivators: financial (monetary) and non-financial (non-monetary). Non-monetary motivators can be divided into material motivators, or all those which an employee receives in non-financial form yet that can be expressed in financial terms, and non-material motivators, which cannot be expressed in financial terms yet have certain meaning and value for employees [3]. The literature presents broad information on work motivation - the papers on lack of motivation (demotivation) are much scarcer. Demotivation is not an explicitly reverse process to motivation. Demotivation is understood as a set of factors resulting in reluctance to the performed work. It is important to remember that demotivation may arise also when an employee encounters certain obstacles at work which make the work difficult despite the real willingness to do the work on the employee's side [4].

The literature on motivation usually refers to the representatives of all types of professions, including health care professions, the group occupational therapists belong to. The responsible and demanding character of work of an occupational therapists is reflected in its work ethics, which clearly defines the responsibilities and code of practice towards the recipients of therapy and their families and environment, towards co-workers, and towards the therapists themselves [5]. The profession of an occupational therapists necessitates constant learning, updating and broadening the knowledge, as well as striving for a broadly understood development. This requires maintaining high level of motivation [6]. Health care professionals should derive their fundamental motivation for performing their professional tasks and obligations from the willingness to help people in need. Still, in the context of work related burden and work related costs the willingness to help people may not a sufficient motivator. This is why it is essential to monitor motivation levels of health care professionals and to take actions which would ensure maintaining its optimal level [7]. Health care managers should remember that a properly motivated employee performs their obligations better, which is important both for the organization and for the patient.

All of the above led us to believe that it is important to direct our attention to the profession of occupational therapists, a group that is often omitted in study projects on health care professions. The aim of our study was to determine the motivators and the demotivators in professionally active occupational therapists.

\section{Material and methods}

The study focused on finding the answer to the following research question: which factors motivate and which factors demotivate professionally active physical therapists for work?

We formulated the following detailed research questions:

1. What factors motivate respondents for work?

2. What factors demotivate respondents for work?

3. Does the workplace diversify motivation levels for professional work? If yes, how?

4. Does the workplace diversify satisfaction with individual factors related to work? If yes, how?

5. Does the work experience diversify occupational therapists' opinion on the statement that the remuneration for professional work is adequate for the therapist's qualifications, experience and involvement in the work? If yes, how?

6. Does the work experience diversify motivation levels for professional work? If yes, how?

7. Does the therapists' age diversify the answers on demotivators in the profession of occupational therapists?

To conduct the study, we used the diagnostic survey method and the technique of questionnaire. The study tool was a questionnaire which we designed for the purpose of this study. The questionnaire consisted of 20 questions and additional items on respondents' sociodemographic data. To select the study population, we used nonprobability sampling. We selected the respondents from the group of professionally active occupational therapists. We distributed questionnaires in two forms - the paper version and the electronic version. We sent paper version questionnaires to chosen welfare and health care institutions, located in the Podkarpackie and Małopolskie voivodships, which employed occupational therapists. We posted the electronic version questionnaires on internet forums dedicated to occupational therapies, and we also sent them by email to those respondents who expressed their consent to participate in the study. In total, we collected 317 questionnaires. We had to decline 22 questionnaires as they lacked considerable amounts of information. We conducted statistical analysis of data from 295 questionnaires.

The study population consisted of 295 occupational therapists, of which $96 \%$ were women. The sexes were nor represented equally as occupational therapists are predominantly females. This tendency is true not only in Poland - for instance, it is estimated that only $8 \%$ of 
US occupational therapists are men; in Canada this estimate is $4 \%$. The majority of respondents were from the age group of 26-35 years (41\%). The mean age (M) was 35 years. The standard deviation for age (SD) was 0.98 . Most respondents worked in towns with 50 to 100 thousand citizens (33\%). The most commonly declared type of qualification enabling to become an occupational therapist was vocational college (49\%). The respondents worked in vocational therapy workshops $(25 \%)$, hospitals (21\%) and community care homes (20\%), and the typical number of years of professional experience was 5 years $(49 \%)$. All the respondents were employed in publically funded institutions. Table 1 presents detailed demographic data.

Tab. 1. Socio-demographic data

\begin{tabular}{|c|c|c|}
\hline Variable & Number & Percentage \\
\hline \multicolumn{3}{|l|}{ Sex } \\
\hline Female & 282 & $96 \%$ \\
\hline Male & 13 & $4 \%$ \\
\hline \multicolumn{3}{|l|}{ Age } \\
\hline Under 25 years & 50 & $17 \%$ \\
\hline $26-35$ years & 120 & $41 \%$ \\
\hline $36-45$ years & 86 & $29 \%$ \\
\hline $46-55$ years & 32 & $11 \%$ \\
\hline Over 55 years & 7 & $2 \%$ \\
\hline \multicolumn{3}{|l|}{ Number of citizens of the place in which the respondent works } \\
\hline Village & 54 & $18 \%$ \\
\hline Town with 50 to 100 thousand citizens & 98 & $33 \%$ \\
\hline Town with 100 to 150 thousand citizens & 46 & $16 \%$ \\
\hline Town with 150 to 200 thousand citizens & 31 & $11 \%$ \\
\hline City with over 200 thousand citizens & 66 & $22 \%$ \\
\hline \multicolumn{3}{|c|}{ Type of qualification enabling to perform the profession of occupational therapist } \\
\hline A course & 9 & $3 \%$ \\
\hline Vocational college & 146 & $49 \%$ \\
\hline University degree in occupational therapy & 51 & $17 \%$ \\
\hline University degree, major in occupational therapy & 42 & $14 \%$ \\
\hline Postgraduate studied & 27 & $9 \%$ \\
\hline Other (disability pedagogist, psychologist, pedagogist) & 20 & $7 \%$ \\
\hline \multicolumn{3}{|l|}{ Workplace } \\
\hline Vocational therapy workshops & 75 & $25 \%$ \\
\hline Community Care Home & 58 & $20 \%$ \\
\hline Nursing Home & 25 & $8 \%$ \\
\hline Hospital & 63 & $21 \%$ \\
\hline Community Day Care Centre & 36 & $12 \%$ \\
\hline Other & 38 & $13 \%$ \\
\hline \multicolumn{3}{|l|}{ Years of professional experience } \\
\hline up to 5 years & 144 & $49 \%$ \\
\hline 6-10 years & 80 & $27 \%$ \\
\hline $11-15$ years & 36 & $12 \%$ \\
\hline $16-20$ years & 17 & $6 \%$ \\
\hline over 20 years & 18 & $6 \%$ \\
\hline
\end{tabular}


We conducted quantitative statistical analysis of the data collected in the questionnaires. We used Spearman's rank correlation coefficient to assess correlation between individual indexes. We set statistical significance at $\alpha=0.05$.

This was a non-invasive study in the scope of social sciences, therefore consent of Ethics Commission was not required. All the respondents expressed informed consent to complete the questionnaire. The study was conducted according to Helsinki Declaration (1964). The study was registered under the number 208/BS/ KTZ/2019 by the University affiliated by the authors.

\section{Results}

The studied occupational therapists were asked to assess their current level of motivation for professional work. The largest group of respondents assessed it as rather high (49\%). Only $10 \%$ of respondents assessed it as very high. $30 \%$ of respondents assessed it as ambivalent. $4 \%$ of respondents assessed their motivation as very low, and $10 \%$ - as rather low.

Then, the respondents referred to 12 motivating factors, indicating their level of satisfaction with each of the factors. The factors were the following: remuneration, stability and safety of employment, development opportunities: training and courses, opportunities for promotion, benefits: bonuses and prizes, respect and recognition from one's supervisor for the work done, friendly atmosphere and interpersonal relationships at work, being able to observe effects of therapy in patients, satisfaction derived from helping another person, the sense of usefulness and meaning of one's work, workplace equipment, autonomy at work, taking initiative. The respondents assessed their satisfaction levels with each of the above factors, and they used the fivepoint Likert scale. In this analysis, we present only those factors which respondents were most satisfied with. The motivator that was rated highest among the respondents was the stability and safety of employment. As many as $53 \%$ of respondents reported that they were rather satisfied with this factor, while $11 \%$ were very satisfied, and $20 \%$ had an ambivalent attitude to it. Only $4 \%$ were very dissatisfied with it and $13 \%$ were rather dissatisfied. The next factor that the respondents expressed high satisfaction with were the effects of occupational therapy they could observe in their patients. As many as $51 \%$ of respondents reported they were rather satisfied with the effects of therapy in their patients, and $31 \%$ reported they were very satisfied. Only $2 \%$ reported they were very dissatisfied with therapy effects, and $5 \%$ reported they were rather dissatisfied. $11 \%$ of respondents had ambivalent attitude to it. We asked the therapists to assess their satisfaction related to helping other people. Most respondents (61\%) were very happy or rather happy (27\%) to be able to help another person. $3 \%$ were dissatisfied or very dissatisfied, respectively. $6 \%$ responded they were neither satisfied nor dissatisfied.

The next item in the questionnaire concerned the factors which the respondents believed to be most demotivating in the profession of an occupational therapist. This was a semi-open question, and the respondents were asked to indicate a maximum of three factors. Inadequate remuneration was the most often reported demotivating factor (28\%). 14\% of respondents found lack of general understanding for the role of an occupational therapist and for the potential of occupational therapy in comprehensive rehabilitation demotivating. The remaining indications were the following: $12 \%$ respondents found lack of opportunities for development demotivating, $10 \%$ reported high emotional costs at work, and inadequate funding for equipping their workplace, respectively. $6 \%$ reported being overloaded with work, and $4 \%$ - competition within the therapeutic team. Only few respondents $-3 \%$ - reported boring work routine as demotivating factors. The least common indication were poor effects of therapeutic activity $(2 \%)$. The significance value $p<0.05$ in the chi-squared test informed of significant differences between the respondents' opinions.

The following item we decided to study was whether the workplace diversified the respondents' motivation for work. The correlation revealed significant relationships between the workplace and work motivation levels $(p<0.05)$. Positive values of Spearman's rank correlation coefficient indicated that work motivation levels were higher in therapists employed in Hospitals and Community Day Care Centres than in therapists employed in Community Care Homes, Occupational Therapy Workshops or Nursing Homes. Table 2 presents detailed data.

The following factor we studied was whether the workplace diversified the respondents' satisfaction with individual work-related factors. The correlation

Tab. 2. Spearman's rank correlation coefficient for the current work motivation level and the workplace

\begin{tabular}{lc}
\hline Contingency variable & Spearman's rank correlation coefficient (p-value) \\
\hline Current work motivation level \& workplace & $\mathrm{r}=0.52(\mathrm{p}=0.034)$ \\
\hline
\end{tabular}


revealed significant relationships between the workplace and satisfaction with individual work-related factors, i.e. remuneration, promotion, friendly atmosphere and friendly interpersonal relationships at work, and satisfaction with being able to help another person $(p<0.05)$. Positive values of Spearman's rank correlation coefficient indicated that therapists employed in Hospitals and Community Day Care Centres assessed the above mentioned factors higher than therapists employed in Community Care Homes, Occupational Therapy Workshops or Nursing Homes. Table 3 presents detailed data.

The following factor we decided to study was whether the years of professional experience diversified the therapists' opinion on whether their remuneration was adequate in relation to their qualifications, experience and work involvement. The correlation revealed significant relationships between years of professional experience and therapists' opinion on their remuneration $(p<0.05)$. Negative values of Spearman's rank correlation coefficient indicated that opinion on inadequacy of remuneration in relation to qualifications, experience and work involvement intensified with years of professional experience. Table 4 presents detailed data.
The following factor we decided to study was whether the years of professional experience diversified the therapists' work motivation. We did not find significant correlations $(\mathrm{p}>0.05)$

The last factor we decided to study was whether the therapists' age was related to the factors which they indicated as most demotivating in occupational therapists' work. The correlation revealed significant relationships between respondents' age and work demotivating factors: remuneration that was inadequate to work performed and lack of professional development perspectives $(p<0.05)$. Positive values of Spearman's rank correlation coefficient indicated these factors were more often reported as demotivating with increasing age of therapists. Table 5 presents detailed data.

\section{Discussion}

The motivation system used in health care institutions should guarantee their employees such working conditions which would satisfy their living standard needs, as well as enable them to develop and increase their qualifications. An equally important area with

Tab. 3. Spearman's rank correlation coefficient for workplace and satisfaction with individual work-related factors

\begin{tabular}{ll}
\hline \multicolumn{1}{c}{ Contingency variable } & $\begin{array}{c}\text { Spearman's rank correlation } \\
\text { coefficient }(\mathrm{p} \text {-value })\end{array}$ \\
\hline $\begin{array}{ll}\text { Remuneration } \\
\text { Stability and safety of employment }\end{array}$ & $\mathrm{r}=0.45(\mathrm{p}=0.03)$ \\
Development opportunities: training and courses & $\mathrm{r}=0.21(\mathrm{p}=0.18)$ \\
Opportunities for promotion & $\mathrm{r}=-0.17(\mathrm{p}=0.09)$ \\
Benefits: bonuses and prizes & $\mathrm{r}=0.38(\mathrm{p}=0.041)$ \\
Respect and recognition from one's supervisor for the work done & $\mathrm{r}=0.1(\mathrm{p}=0.89)$ \\
Friendly atmosphere and interpersonal relationships at work & $\mathrm{r}=-0.03(\mathrm{p}=0.98)$ \\
Being able to observe effects of therapy in patients & $\mathrm{r}=0.41(\mathrm{p}=0.02)$ \\
Satisfaction from helping another person & $\mathrm{r}=0.05(\mathrm{p}=0.95)$ \\
The sense of usefulness and meaning of one's work & $\mathrm{r}=0.56(\mathrm{p}=0.01)$ \\
Workplace equipment & $\mathrm{r}=0.07(\mathrm{p}=0.91)$ \\
Autonomy at work, taking initiative & $\mathrm{r}=-0.09(\mathrm{p}=0.79)$ \\
\hline
\end{tabular}

Tab. 4. Spearman's rank correlation coefficient for years of professional experience and the therapists' opinion on whether their remuneration was adequate in relation to their qualifications, experience and work involvement

\begin{tabular}{lc}
\hline Contingency variable & Spearman's rank correlation coefficient $(\mathrm{p}$-value $)$ \\
\hline $\begin{array}{l}\text { Years of professional experience \& the therapists' opinion on } \\
\text { whether their remuneration was adequate in relation to their }\end{array}$ & $\mathrm{r}=-0.78(\mathrm{p}=0.01)$ \\
qualifications, experience and work involvement & \\
\hline
\end{tabular}


Tab. 5. Spearman's rank correlation coefficient for age and work demotivating factors at occupational therapists' work

\begin{tabular}{ll}
\hline Contingency variable & $\begin{array}{c}\text { Spearman's rank correlation } \\
\text { coefficient }(p-v a l u e)\end{array}$ \\
\hline Unregulated status of profession & $r=0.19(p=0.75)$ \\
Remuneration inadequate to the work performed & $r=0.87(p=0.01)$ \\
Lack of development perspectives (promotion, increasing qualifications) & $r=0.57(p=0.01)$ \\
$\quad$ Lack of financial means to properly equip the workplace and workstations & $r=-0.21(p=0.69)$ \\
Age $\quad$ Emotional costs: stress, tiredness, sense of powerless & $r=0.09(p=0.91)$ \\
$\quad \begin{array}{l}\text { Poor effects of therapeutic activities } \\
\text { Work overload, complexity of work }\end{array}$ & $r=-0.31(p=0.08)$ \\
Boring work routine & $r=0.24(p=0.11)$ \\
Lack of general understanding for the role of an occupational therapist and & $r=0.30(p=0.09)$ \\
for the potential of occupational therapy in comprehensive rehabilitation & $r=0.16(p=0.83)$
\end{tabular}

motivational impact is supporting the social aspects of work, the need for belonging, respect and recognition [8]. Undoubtedly, the profession of occupational therapists requires adequate motivation. Remarkably, there are numerous studies on work motivation among health care workers [9], yet data on motivation of occupational therapists is difficult to access [10].

Occupational therapists' working conditions and scope of responsibilities, seen as factors which impact their work motivation, are to a large extent dependent on the place and sector they are employed in [11]. Occupational therapists are employed by institutions which differ in terms of organizational and administrative structures, as well as in the sector they function in (the public sector and the private sector) [12]. Occupational therapists who participated in this study were employed both in health care institutions and in social care institutions. Most of the therapists were employed at Occupational Therapy Workshops, in Hospitals and Social Care Homes.

Our study showed that the workplace of the studied therapists did not diversify their opinion on their employer's motivating activities, or on therapists' opportunities for development and increasing professional qualifications at the workplace. Regardless of the workplace, most therapists believed that their employer did not take any motivating activities. When asked to name motivation activities most often used at their workplaces, they usually reported that their employer did not take any motivation activities, and if there were any, they usually had the form of praising or other, verbal or non-verbal, forms of expressing recognition. More than half of the respondents claimed that their workplace did not offer any opportunities for development or for increasing professional qualifications. Still, the workplace diversified the studied therapists' work motivation and satisfaction with certain aspects of their work. Basing on the analysis of the collected data we found significant relationships between the therapists' workplace and their work motivation levels and satisfaction with certain work-related factors (remuneration, opportunities for promotion, friendly atmosphere and interpersonal relationships at work, satisfaction derived from helping another person).

The results of our study can be compared to the studies conducted in United Kingdom, Africa and Asia. These studies found that individual organizational factors at the workplace can have significant impact on the motivation levels in health care professionals. Motivation may be determined by culture, traditions, and the economic situation of a given institution. Several organizational aspects were believed to have essential value in this process. These were: financial incentives, creating opportunities for development, the character of the workplace and the approach to management and leadership [13].

The data quoted by a PFRON report (State Fund for Rehabilitation of Disabled People in Poland) outline the main problems among the staff employed at Occupational Therapy Workshops. These difficulties often result in high staff turnover, and consequently difficulties with recruitment and maintaining staff with appropriate competences and work experience. According to the data from this report the main difficulties were: poor remuneration $(31 \%)$, lack of training funds (4\%) and lack of adequate motivating strategies for the employed staff (no bonuses etc.). Also, it was found that Occupational Therapy Workshops were understaffed and that the existing staff suffered from professional burnout (9\%) [14]. The therapists involved in our study 
also expressed dissatisfaction with their remuneration, which they believed to be rather poor. Our study showed that with longer work experience the therapists reinforced their opinions on the inadequacy of their remuneration in relation the their qualifications, professional experience and involvement in work. The same tendency was found in the study on work satisfaction among Polish physiotherapists. That study showed that employees with fewer years of experiences were more satisfied with some aspects of their work, and that with greater number of years of experience the satisfaction levels decreased [15].

Work motivation levels can be shaped by demographic data, such as age and years of professional experience. Professional experience may impact work motivation, one's competences and knowledge [16]. Even though the length of professional experience may impact work motivation, some studies show that it does not determine work motivation level [17]. Our study has not shown statistically significant differences between studied therapists' years of professional experience and their work motivation. Similarly, such relationship was not found in a 2017 study by S.C. Chai, R. Teoh and F. Razaob on occupational therapists. Their study showed that occupational therapists with fewer years of professional experience had similar work motivation levels as therapists with longer professional experience [10].

\section{Conclusions}

Our study and the analysis of the collected data allowed us to draw the following conclusions:

1. Work motivating factors that the respondents reported most often were: high level of satisfaction from the stability and safety of employment, being able to notice the effects of their therapeutic actions in their patients, the feeling of helping another human being, the atmosphere and the quality of interpersonal relationships at work.

2. The most commonly reported demotivating factor was receiving remuneration which was inadequate to the work performed. Other demotivating factors were: lack of general understanding for the role of an occupational therapist and for the potential of occupational therapy in comprehensive rehabilitation.

3. The workplace diversified the respondents' motivation for work. Work motivation levels were higher in therapists employed in Hospitals and Community Day Care Centres than in therapists employed in Community Care Homes, Occupational Therapy Workshops or Nursing Homes.

4. The workplace diversified the respondents' satisfaction with individual work-related factors.
Therapists employed in Hospitals and Community Day Care Centres assess their satisfaction with remuneration, promotion, friendly atmosphere and friendly interpersonal relationships at work, and satisfaction with being able to help another person higher than therapists employed in Community Care Homes, Occupational Therapy Workshops or Nursing Homes.

5. The number of years of professional experience diversified the therapists' opinion on whether their remuneration was adequate. Their opinion on inadequacy of remuneration in relation to qualifications, experience and work involvement intensified with years of professional experience.

6. The length of professional experience did not determine therapists' work motivation level.

7. The occupational therapists' age diversified their indications on most demotivating factors in their work. With therapists increasing age, their indications of remuneration being inadequate to work performed and lack of professional development perspectives were more often reported as demotivating in an occupational therapists' work.

\section{Funding}

This research received no external funding.

\section{Conflicts of interest}

The authors declare no conflict of interest.

\section{References}

1. Armstrong M. Zarządzanie zasobami ludzkimi. Kraków: Wolters Kluwer; 2010.

2. Sekuła Z. Motywowanie do pracy. Teorie i instrumenty. Warszawa: PWE; 2008.

3. Kopertyńska MW. Motywowanie pracowników. Teoria i praktyka. Warszawa: Wydawnictwo PLACET; 2008.

4. Dolot A. Źródła demotywacji pracowników w świetle badań empirycznych. Studia Ekonomiczne. Zeszyty Naukowe Uniwersytetu Ekonomicznego w Katowicach. 2015; (229):21-34.

5. American Occupational Therapy Association. Occupational Therapy Code of Ethics. Am J Occup Ther. 2015; (69): 6913410030p1-6913410030p8.

6. Janus E. Rozwój zawodowy terapeuty zajęciowego. In: Misiorek A., Janus E., Kuśnierz M., Bugaj R. Współczesna terapia zajęciowa. Warszawa: PZWL. 2019; s. 165-73.

7. Czerw A, Borkowska A. Praca zawodowa jako obszar realizowania misji społecznej. Psych Społ. 2010; 4(15): 303-15. 
8. IInicka P. Organizacja i zarządzanie podmiotami leczniczymi. Otoczenie i nowe wyzwania. Przegl Pr i Adm. 2017; 1(11): 63-78.

9. Perreira TA, Innis J, Berta W. Work motivation in health care: a scoping literature review. Int J Evid Base Health. 2016; 14(4):175-82.

10. Chai SC, Teoh RF, Razaob, et al. Work Motivation among Occupational Therapy Graduates in Malaysia, Hong Kong. J Occup Th. 2017; 30(1): 42-8.

11. Szyszka M. Doradztwo, poradnictwo i wsparcie jako role i zadania terapeuty zajęciowego. Terapia zorientowana na poszerzenie obszarów partycypacji i współpracę w środowisku klienta [In:] Doradztwo - poradnictwo - wsparcie. Płonka-Syroka B, Dąsal M, Wójcik W (red). Warszawa, DiG, 2015; s. 353-73.

12. Matecka M. Wymierne versus niewymierne źródła satysfakcji z pracy. [In:] Profesjonalne zarządzanie kadrami w podmiotach leczniczych, Głowacka MD, Mojs E (red). Wolters Kluwer, Warszawa 2015; s. 144-53.
13. Perreira TA, Innis J, Berta W. Work motivation in health care: a scoping literature review. Int J Evid Base Health. 2016; 14(4): 175-82.

14. Morysińska A, Sochańska-Kawiecka M, MakowskaBelta E, et al. Badanie sytuacji warsztatów terapii zajęciowej. Raport końcowy z badania. Państwowy Fundusz Rehabilitacji Osób Niepełnosprawnych. Warszawa 2014; 243-5.

15. Barabasz K, Gębska M, Weber-Nowakowska K. Assessment of occupational satisfaction of physiotherapists in West Pomeranian Region. J Educ Health Sport. 2017; 7(9): 471-91.

16. Kłak D. Determinanty motywacji kapitału ludzkiego organizacji w świetle badań empirycznych. Hum and Soc Sci. 2018; 25(3):131-41.

17. Urošević S, Milijić N. Influence of demographic factors on employee satisfaction and motivation. Organizacja. 2015; 45(4): 174-82. 